\title{
İntihar ve Toplumsal Cinsiyet: Sosyal Hizmet Perspektifinden Bir Değerlendirme
}

DOI: $10.26466 /$ opus.605613

\author{
Sinan Akçay* - Mervenur Taşkın** \\ * Dr, Öğr.Üy., Selçuk Üniversitesi, Sağlık Bilimleri Fakültesi, Sosyal Hizmet Böl.,Konya / Türkiye \\ E-Posta: sinan.akcay@selcuk.edu.tr \\ ORCID: 0000-0001-9485-5891 \\ ** Y. L. Öğrencisi., Selçuk Üni., Sağlık Bilimleri Fakültesi, Sosyal HizmetBöl.,Konya/Türkiye \\ E-Posta: mnnurtaskin@gmail.com ORCID: 0000-0002-5404-2826
}

Öz

Intihar bireyi ve bireyi çevreleyen sistemleri etkileyen önemli bir halk sağll̆ğı sorunudur. İntihar kavramı bu çalışmada tamamlanmış intiharlar ve intihar girişimleri olmak üzere iki şekilde ele alınmaktadır. Tamamlanmış intiharlar ölümle sonuçlanırken,intihar girişimleri bireyin kendisine yönelik zarar verici davranışlarda bulunmasıdır. Yapılan çalışmalar tamamlanmış intiharlarda erkeklerin, intihar girişimlerinde ise kadınların sayısının daha fazla olduğunu göstermektedir. Erkekler hegemonik erkeklik baskısı altında geleneksel eril cinsiyet rollerini devam ettirmekte, başarısız olma endişesi veya başarısızlık algısı ile intihar davranışına başvurabilmektedir. Kadınların intihar davranışında da toplumsal cinsiyet düzeninden kaynaklanan sorunların ve toplumsal cinsiyet rol beklentilerinin etkileri büyüktür. LGBTi'lerin intihar davranışlarında ise yaşadıkları dışlanmışlık ve ayrımcı davranışların önemli bir etkisi bulunmaktadır. Tamamlanmış intihar ve intihar girişimlerindeki oranların cinsiyete göre dă̆̆llımı, seçilen intihar yöntemi ve intihar davranışına başvurma nedenlerine bakıldı̆̆ında toplumsal cinsiyetin etkisi görülmektedir. Tüm bunlar intihar davranışlarında toplumsal cinsiyetin göz ardı edilmemesi gerektiğine işaret etmektedir. Bu çalışmada intihar toplumsal cinsiyet perspektifinden ele alınmakta ve intihar davranışında toplumsal cinsiyete duyarl sosyal hizmet uygulamalarını önemi vurgulanmaktadır.

Anahtar Kelimeler: İntihar, Toplumsal Cinsiyet, Sosyal Hizmet 


\title{
Suicide And Gender: An Evaluation From The Perspective of Social Work
}

\begin{abstract}
Suicide is an important public health problem affecting individuals and the systems surrounding them. In this study, suicide concept is considered in two ways as completed suicides and suicide attempts. Completed suicides result in death and suicide attempts are self-destructive behaviors. Studies show that while completed suicides are more in men, suicides attempts are more in women. Under the pressure of the hegemonic masculinity, men maintain their traditional masculine gender roles and may resort to suicidal behavior with the fear of failure or perception of failure. Women's suicidal behavior also has a major impact on gender-related problems and gender role expectations. Exclusion and discriminatory behaviors towards LGBTI individuals have a significant effect on suicidal behavior. When the distribution of the rates of completed suicide and suicide attempts according to sex, the selected suicide method and the reasons for suicide behavior are examined, the effect of gender is seen. All these points to the fact that gender should not be ignored in suicidal behavior. In this study, suicide is discussed from a gender perspective and the importance of gender sensitive social work practices in suicidal behavior is emphasized
\end{abstract}

Keywords: Suicide, Gender, Social Work 


\section{Giriş}

İntihar bireyin yaşamına son vermesidir. “Ölmek amacıyla planlı ve kasıtlı bir girişimde bulunmak" olarak tanımlanmaktadır (Siyez, 2006). İntihar tamamlanmış intihar ve intihar girişimi olarak ikiye ayrılmaktadır. Tamamlanmış intiharlar ölümle sonuçlanırken, intihar girişimleri bireyin kendisine zarar verici davranışlarından oluşmakta ancak ölümle sonuçlanmamaktadır.

İntihar bireysel, ruhsal, kültürel, toplumsal birçok yönü olan bir olgudur ve her yönünün ayrıntılı olarak ele alınması gerekmektedir (Dilbaz ve ark., 2005). Önemli bir halk sağlığı sorunu olan intiharların (Yumru ve ark., 2008) Türkiye'deki artış hızı ile beraber artık toplumsal bir sorun olma niteliği taşıdığı görülmektedir (Şevik ve ark., 2012). Türkiye'de 2014 yılında ölümle sonuçlanan intihar sayısı 2015 yılında artış $(\% 1,3)$ göstermektedir ve 2015 yllinda intihar edenlerin \%72,7 'sinin erkek, \%27,3' ünün kadınlar olduğu belirtilmektedir. Verilere göre 2015 yılında her yüz bin kişiden dördü intihar etmiştir (TUİK, 2015). Dünya Sağlık Örgütü (DSÖ) de her yıl 800 000'e yakın kişinin intihar nedeniyle hayatını kaybettiğini vurgulamaktadır. Bu her 40 saniyede bir kişinin intihar etmesi, yaşamına son vermesi demektir. 15-29 yaş arasındaki ölüm nedenleri arasında intihar ikinci önde gelen ölüm nedenidir ve intihar girişimleri tamamlanan intiharlardan 20 kat daha fazladır (DSÖ, 2014).

Giderek yaygınlığı artan intihar olgusunun çeşitli risk faktörleri ve koruyucu faktörlerinden söz etmek mümkündür. İntihar ve intihar girişimlerine bakıldığında birtakım risk faktörleri ön plana çıkmaktadır. İntihar ve intihar girişimlerinin 15-25 yaş aralığında en fazla görüldüğü belirtilmektedir. Tamamlanmış intiharlar erkeklerde, intihar girişimleri kadınlarda daha fazla görülmektedir. Bekar bireylerin intihar etme ve intihar girişimlerinde bulunma oranı daha fazladır ancak evli bireylerin de oranı azımsanamayacak düzeydedir. Düşük eğitim seviyesi intiharlar için bir risk oluşturabilmektedir. Ruhsal hastalığa sahip olma veya psikiyatrik tanı alma durumu intiharlar için belirleyici olabilmektedir (Özel ve ark., 2008; Önsüz ve ark, 2012; Arslan ve ark., 2008; Dilbaz ve ark., 2005; Yavuz ve ark., 2006; Şevik ve ark., 2012; Karamustafalığlu ve ark., 2010; Kuğu ve ark., 2002; Fennig ve ark, 2005; Atay ve ark., 2012; Kessler 
ve ark., 1999). Ayrıca intihar girişimleri de tamamlanmış intihar için bir risk faktörüdür. Bireylerin tekrar intihar girişiminde bulunmaları gibi bir durum söz konusu olabilmektedir. Diğer bir yandan bireylerin hayata bağlllıkları, sağlık durumundan memnuniyet, yardım arama davranışı, sosyal destek gibi unsurlar ise koruyucu faktörler arasında yer almaktadır (Atay ve ark., 2012; Gürkan ve Dirik, 2009; Batıgün, 2008).

İntihar davranışının önemli belirleyicilerinden biri de toplumsal cinsiyettir. $\mathrm{Bu}$ çalışmada da toplumsal cinsiyetin intihar davranışı üzerindeki etkisi tartışlacak ve sosyal hizmet açısından toplumsal cinsiyete duyarlı sosyal hizmet müdahalelerine değinilecektir.

\section{İntihar Ve Toplumsal Cinsiyet}

Toplumsal cinsiyet kavramı, biyolojik farklılıklar ile açılanmakta olan cinsiyet (sex) kavramından farklı olarak ele alınmaktadır. Toplumsal cinsiyet (gender) kadın ve erkeğe kültürel ve toplumsal değerler kapsamında yüklenen çeşitli roller ve sorumluluklardır. Bu noktada toplumsal cinsiyet topluma göre ve zamana göre değişim gösterebilmektedir (Demirgöz Bal, 2014). Toplumsal değerler ile şekillenmekte olan ve kadına ve erkeğe ayrı roller yükleyen toplumsal cinsiyet, kadını "kırllgan, edilgen, karmaşık, ilgi bekleyen, bağımlı" gibi kavramlarla tanımlarken erkeği "koruyucu-kollayıcl-sahiplenici, yöneten, yönlendiren" gibi kavramlarla tanımlamaktadır (Kurt-Topuz ve Erkanlı, 2016). Kadın ve erkeğe farklı anlamlar ve roller yüklenilmesi toplumsal cinsiyet eşitsizliğinin temelini oluşturmaktadır. Toplumsal cinsiyet eşitsizliği birçok alanda kendini göstermektedir. Özel alan ve kamusal alan ayrımı, kadının çalışma yaşamında karşılaştığı güçlükler, ev içi işlerde yapılan işbölümü, eğitim, sağlık gibi alanlar bu eşitsizliğin görüldüğü alanlardır. Yaşanan bu toplumsal cinsiyet eşitsizliğinde kadın ve erkeğe yüklenen kalıp düşünceler ve keskin sınırlarla ayrılmış rollerin etkisi büyüktür (Altınova ve Duyan, 2013). Toplumsal cinsiyetin ve yaşanan eşitsizliğin sosyal süreçler içerisinde pekiştirildiğinin altı çizilmelidir. En nihayetinde ortaya çıan bu eşitsizlik durumu toplumdaki her bir bireyin iyilik hali bakımından önemli bir sorun olma niteliği taşımaktadır.

Toplumsal cinsiyet eşitsizliği çeşitli alanlarda olduğu gibi bireylerin ruh sağlı̆ıını da olumsuz etkilemektedir. Yaşanan eşitsizlikler bireylerin 
sahip olduğu güçleri kullanamaması, kaynaklara ulaşamaması, karar verici konumda olamamaları gibi birçok olumsuz özellikleri beraberinde getirmektedir. Toplumun kadına ve erkeğe yüklediği roller değerlendirildiğinde kadınlar dezavantajlı bir konumdadır. Nitekim ruh sağlığı alanına bakıldığında tüm dünyada erkeklere göre kadınlar daha fazla ruhsal hastalık tanısı almaktadır (Ançel, 2018). Toplumsal cinsiyet normları, ruh sağlığı alanında belirli rollere uyması beklenen bireylerin bu roller dışına çıkması durumunda bir baskı unsuru olarak karşımıza çıkmaktadır. Kadınların ruhsal hastalık oranlarının erkeklerden daha fazla olmasında kadının durumunu kabullenmesi ve tedavi arayışında olması, toplumun kadının zayıf ve incinebilir yapısı gereği böyle bir hastalık durumunu normal ve olağan kabul etmesi gibi durumlar söz konusu olmaktadır (Yaşar, 2007). Bu durum kadınlar açısından olduğu gibi erkekler açısından da ruh sağlığı alanında olumsuzluklar meydana getirmektedir. Kadınlar, LGBTI bireyler ve erkekler belirlenen rol ve sorumluluklara, atfedilen kavramlara uymadığında ruhsal açıdan birtakım sorunlarla karşılaşmaktadır. Kadın çeşitli hastalıklarla en çok bağdaştırılan cinsiyet olmakta, LGBTi bireyler homofobik ve damgalanma davranışlarıyla karşılaşmakta, erkekler ise güçlü olmakla bağdaştırıldığı için yaşadıkları ruhsal sorunlar karşısında yardım arama davranışı göstermekten kaçınmakta, sağlıklı olmayan çözümler geliştirmektedir.

Toplumun bireylerden beklentilerini kapsayan toplumsal cinsiyet kavramı bireylerin intihar davranışlarını açıklamada önemli bir yere sahiptir. Tamamlanmış intihar ve intihar girişimi olarak ele alınan intihar davranışında toplumsal cinsiyet belirleyici olmaktadır. Yapılan çalışmalar göstermektedir ki kadınlar erkeklerden daha fazla intihar girişimlerinde bulunmakta, tamamlanmış intiharlar ise erkeklerde daha fazla görülmektedir (Özel ve ark., 2008; Önsüz ve ark., 2012; Arslan ve ark., 2008; Dilbaz ve ark., 2005; Karamustafalığlu ve ark., 2010; Şevik ve ark., 2012). Bu durum kadına yüklenen zayıflık, incinebilirlik, bağımlılık, sosyal destek ihtiyacı gibi kavramların bir sonucu olarak kadının yardım arama, sesini duyurma amacıyla intihar girişimlerinde bulunmalarını açıklamaktadır. Erkeklerde ise başarı kavramı öne çıkmaktadır. Tamamlanmış intihar toplum açısından bakıldığında "başarılı" intiharlardır ve başarı, başarılı olmak erkeğe atfedilen bir kavramdır. Bu 
noktada erkeklerin bir çözüm arayışında olmadığı, intihar ile ölümü amaçladığ1 ve bunu "başardığı" yönünde bir alg1 söz konusudur. Bir çalışmada yapılan odak grup görüşmesinde kadınların intiharı bir yardım arayışı nedeniyle gerçekleştirdikleri erkeklerin ise yaşamı sona erdirmek gibi bir düşüncelerinin olduğu yönünde düşünceler belirtilmektedir. Erkeklerin yardıma muhtaç olmaktansa kesin bir şekilde yaşamı reddetmeyi seçtikleri ifade edilmektedir (Scourfield ve ark., 2007). LGBTİ bireyler açısından bakıldığında toplum tarafından istenmeyen olmak, dışlanmak ve damgalanmak bireylerin bazen sesini duyurma aracı olarak bazen de çözümsüz kalındığına dair bir düşünce intihar nedeni olabilmektedir.

Toplumsal cinsiyetin intihar davranışı üzerindeki belirleyiciliği intihar davranışında bulunurken seçilen yöntemle de kendisini göstermektedir. Erkekler daha ölümcül yöntemleri kullanmakta, kadınlar ise ölümle sonuçlanma olasılığı düşük olan yöntemleri tercih etmektedir. Seçilen yöntem tamamlanmış intihar ve intihar girişimlerindeki kadın ve erkek oranlarını açıklamaktadır (Scourfield ve ark., 2007; Langhinrichsen-Rohling ve ark., 1998; Canetto ve Lester, 1998). İntihar davranışlarında kullanılan yöntemlere bakıldığında aşırı dozda ilaç alma ve yardım arayışı düşüncesi arasında bir ilişki vardır. Kadınlar intihar davranışında daha çok ilaç içme yöntemini tercih etmektedir. Tüm bunlar göstermektedir ki intiharda kullanılan yöntem "erkek yöntemi" ve "kadın yöntemi" gibi bir değerlendirme sürecine girmektedir (McAndrew ve Garrison, 2007; Swami ve ark., 2008).

Toplumun bireylerden beklediği cinsiyet rollerine ilişkin baskın tutumlar bireylerin bazen bir yardım arayışı bazen bir son olarak intihara başvurmalarına neden olabilmektedir. Böylece intihar davranışı yine toplumun cinsiyetlere keskin sınırlar çizerek belirlediği özelliklere uygun bir şekilde gerçekleştirilmektedir. İntihar girişimlerinde bulunan kadının, tamamlanmış intiharlarda erkeğin daha fazla olması ve seçilen yöntemlerdeki farklılık bunu kanitlamaktadır.

\section{Erkeklerde İntihar Davranışı}

Tamamlanmış intiharlara bakıldığında intihar edenlerin \%72,7' si erkeklerden oluşmaktadır. Ayrıca Türkiye' de erkek intiharları 20-24 yaş 
arasında yoğunluktadır (TÜİK, 2015). Literatürde erkeklerin intihar davranışında bulunma nedenleri ile ilgili olarak öne çıkanlar karşı cinsle ilgili sorunlar (Önsüz ve ark., 2012), iş ile ilgili sorunlar (Atay ve ark., 2012), bunalım (Özel ve ark., 2008) gibi nedenlerdir. Erkek intihar davranışlarında eğitimin de yordayıcı olduğu belirtilmektedir (Batıgün, 2008). İntihar davranışlarında erkeklerin yaşadıkları herhangi bir başarısızlık durumu önemlidir. Herhangi bir konuda başarısız olmak ve bu başarısız olma endişesi intihar davranışlarında belirleyici olabilmektedir (McAndrew ve Garrison, 2007). Toplumsal cinsiyet açısından bakıldığında erkeğe atfedilen başarı, güç, cesaret gibi kavramlar erkek intiharların nedenlerini açıklamaktadır. Erkekler başarılı olmak, iş bulmak, para kazanmak ile nitelendirilmekte ve bunları başaramadığında umutsuzluk yaşayabilmektedir. Yaşadığ ifade etmek, yardım istemek yerine intihar etmek tercih edilebilmektedir (Lubell, 2001). Nitekim toplumun belirlediği erkek cinsiyet rolüne bağlllık erkek intiharlarında etkili olabilmektedir (Batıün, 2008). Geleneksel erkeklik rolleri erkeklerin yaşadığı kırılganlıklar noktasında bir risk faktörü olarak belirtilmektedir. Erkeklerin yardım istemedeki isteksizlikleri, madde kullanımı, erkek cinsiyet rolüne bağlılık, sosyal yaşamdaki değişim ile yaşanan ekonomik sorunlar gibi faktörler geleneksel erkeklik rolleriyle ilgilidir ve intihar davranışlarında önemli bir risk faktörüdür (Moller-Leimkuhler, 2002).

Kadınların ataerkil sistem içerisindeki durumlarına paralel olarak erkekler de bu sistem içerisinde çeşitli baskılar ile karşılaşmaktadır. Bu durum hegemonik erkeklik kavramsallaştırması ile açıklanmaktadır. Hegemonik erkeklik belirli erkeklik özellikleri sunmaktadır. Erkeklerin bu özellikleri taşımaları gerekmekte aksi takdirde çeşitli baskı unsurları ile karşılaşabilmektedirler (Connell ve Messerschmıdt, 2005). Erkeklik özelliklerinin belirlenmesi, sınırlarının koyulması ve bunlara uymayanların ötekileştirilmesi söz konusudur. Bu durum kadınlarda olduğu gibi erkeklerin de erkek hegemonyası ile baskı altına alındığını göstermektedir. Hegemonik erkeklik kavramının öne sürdüğü özelliklere sahip olmayan bireylerin ayrımcı davranışlarla karşılaştığı belirtilmektedir (Şimşek ve Öner, 2015). Hegemonik erkeklik kavramı ayrıcalıklı bir sınıf olarak çeşitli toplumsal davranış kalıplarını ortaya koymaktadır (River, 2014). 
Erkekler yaşadıkları sorunlar karşısında olumsuz duygular yaşamakta, bu problemle başa çıkma mekanizmaları genellikle toplumdaki erkeklik normlarıyla ilişkili olarak işlemektedir. Hegemonik erkekliğin baskın geldiği bu süreçte bireyler yardım aramak yerine intihar etmeyi seçmektedir (Cleary, 2012). River (2014)'in iki intihar vakasından yola çıkarak yaptığı çalışmada toplum tarafından daha "erkeksi" bulunan mesleği kendi istemediği halde seçmiş olmasının birey üzerinde yarattı̆̆ 1 olumsuzluğa değinmektedir. Bu umutsuzluk intiharın belirleyicisi olarak ele alınmaktadır. İstemediği bir işte, toplumun erkeklere uygun gördüğü bir işte çalışmak başarısızlığa neden olabilir ve başarısızlık hissi erkekler üzerinde olumsuz etkiler yaratabilmektedir. Hegemonik erkeklik; erkeklerin para, güç, başarı gibi çeşitli kavramlara sahip olmasını gerekli kılmaktadır. $\mathrm{Bu}$ noktada hegemonik erkeklik baskısı altında olan erkeklerden başarısız olmamaları, başarısız olduklarında yardım aramamaları, sorunlar karşısında duygusal olmamaları beklenmektedir. Böyle bir durum söz konusu olduğunda ise yaşanan sıkıntılara son vermek düşüncesiyle ve yine erkeklik özelliklerine sadık kalarak intihara başvurulmaktadır. Nitekim erkeklerde "başarılı" intiharlar olarak adlandırılan tamamlanmış intiharlar güç, cesaret, kararlılık kavramlarıyla ilişkilendirilmektedir. İntiharlar gücün bir göstergesi olarak algılanmakta ve intihar eden erkekler için cesaret kavramı kullanılmaktadır (Scourfield ve ark., 2007). Erkek intiharları gücün ve saygınlığın kaybedilmesi durumunda tekrar saygınlığ kazanmak için başvurulan başarılı bir tavır olarak görülmektedir (Canetto ve Lester, 1998). Sonuç olarak erkeklerin intihar davranışlarında hegemonik erkekliğin önemli bir belirleyici olduğu görülmektedir.

\section{Kadınlarda İntihar Davranışı}

2015 yılı verilerine göre tamamlanmış intiharlarda kadınların oranı \%27,3' tür. Kadın intiharları 15-19 yaş grubunda yoğunluktadır (TÜİK, 2015). Yapılan çalışmalara bakıldığında kadınlarda intihar davranışlarında aile ile ilgili sorunlar ilk sırada yer almaktadır (Önsüz ve ark., 2012; Atay ve ark., 2012; Özel ve ark., 2008). Aile ile yaşanan herhangi bir sorun, aileden beklenen desteğin alınamaması, aile içi stres faktörlerinin varlığı kadın intiharlarında etkili olmaktadır. Kadınlar 
açısından bakıldığında "sevgi" kavramı kadınlar için hem intihar girişimlerinin bir nedenidir hem de intihar davranışından koruyucu bir işlev görmektedir. Bu durumun kadına toplum tarafından atfedilmiş olan bağımlılık beklentisi ile ilişkili olabileceği belirtilmektedir (Scourfield ve ark., 2007). Cinsiyete özgü bir davranıştan sapma intihar girişimleri için önemli bir risk faktörüdür (Fennig ve ark., 2005). Yapılan bir çalışmada kadın intiharlarında, toplum tarafından belirlenen kadın cinsiyet rollerine uygun olmayan bir iletişim tarzının benimsenmesinin etkili olduğu belirtilmektedir (Batıgün, 2008). Bu durumu kadınlardan beklenen yaşadıklarına bir şekilde katlanması gerektiği düşüncesiyle açıklamak mümkündür. Toplumsal cinsiyet rolleri bağlamında kadın kırılgan, incinebilir olduğu gibi tüm bunlara da katlanması beklenen olarak algılanmaktadır. Kadınlarda intihar davranışına yönelik toplumdaki düşüncelere bakıldığında genellikle özel ilişki ile ilgili bir sorun olduğunda kadınların duygusal ve zayıf bir davranış göstererek intihar girişiminde bulunduğu yönündedir (Canetto ve Lester, 1998). Kadına ait olduğu düşünülen görev ve sorumluluklar gibi kadını tanımladığı düşünülen zayıf, kırılgan gibi kavramlar içerisinde "kadınlık" rollerine vurgu yapılmaktadır. Yaşamın içinde oluşturulmuş olan ve yaşam boyu devam eden toplumsal cinsiyet normları kadınların intihar girişimlerinde etkilidir. Gürkan ve Dirik (2009)'in üniversite öğrencilerinin "yaşamı sürdürme nedenleri" ni incelediği araştırmada kız öğrenciler erkek öğrencilere göre daha fazla yaşamı sürdürme nedeni belirtmektedirler. Ancak intihar girişimlerine bakıldığında kadın oranlarının erkeklerden çok daha fazla olduğu görülmektedir.

Toplumsal cinsiyet rolleriyle bağlantılı olarak kadınların sorunları içselleştirdikleri gibi birileriyle paylaşma ihtiyacı da hissettikleri vurgulanmaktadır (Fennig ve ark., 2005). Sorunlarını paylaşma ihtiyacı duyan kadınların bu konuda yaşadığı eksiklik veya sosyal destek alamama/almama intiharın yordayıcısıdır (Batıün, 2008). Bu noktadan hareketle "kadınsı intihar yöntemi" olan ilaç almak gibi daha az ölümcül intihar yöntemlerinin tercih edilmesinin üzerinde durulması gerekir (McAndrew ve Garrison, 2007). Aşırı dozda ilaç alarak gerçekleştirilen intihar girişimleriyle yardım düşüncesi arasında bir ilişki vardır (Scourfield ve ark., 2007). 
Kadın intihar girişimleri başarısızlık olarak yorumlanmaktadır ve buradaki başarısızlık hayatta kalmak anlamına gelmektedir. Kadınlarda intihar girişimlerinin ölümle sonuçlanması durumunda da bu durumun yanlış planlamalar nedeniyle kazara olduğu düşünülmekte, ölümle sonuçlanmayan intihar girişimleri dahi kadınlar için başarısızlık ile açılanmaktadır (Canetto ve Lester, 1998).

\section{LGBTI'lerde İntihar Davranışı}

LGBTI bireylerin yaşamları boyunca intihar girişiminde bulunma olasılıklarının daha yüksek olduğu belirtilmektedir. Ayrıca 16-27 yaş grubundaki LGBTI gençlerin intihar girişiminde bulunma olasılıkları 5 kat daha fazladır (National LGBTİ Health Alliance, 2016). LGBTI'ler gerek özel alan gerekse kamusal alanda birçok baskı ve ayrımcllık ile dışlanmaya maruz kalmaktadır. LGBTI bireyler toplum tarafından dışlanmakta, olumsuz değerlendirmeler, homofobik tutumlarla karşı karşıya kalmaktadırlar. LGBTI bireyler yaşadıkları dışlanma ve karşılaştıkları olumsuz yargılar karşısında bir baş etme yöntemi olarak intihar davranışına başvurabilmektedir. Toplumsal değerlerden uzak kaldıkları belirtilerek bireylere yönelik ayrımcı davranışlarda bulunmak LGBTI bireylerinin sosyalleşme sürecini olumsuz etkilemekte ve olumsuz duygular deneyimlemelerine sebep olmaktadır. Toplumun yaşattığı ayrımcılık ve ötekileştirme LGBTİ bireylerin intihar davranışlarında belirleyici olmaktadır. Toplum tarafından dışlanma, zedelenen aidiyet kavramı ile değerlendirilmeli, kendi aidiyetlerini sorgulayan bireylerin yaşamlarını sonlandırma düşünceleri ve eylemlerini bu kapsamda değerlendirmek önemli görülmektedir (Erdoğan ve Köten, 2015). LGBTİ bireylere karşı gösterilen bu olumsuz tutum ve davranışlar bireylerin hem kendilerine hem de karşı tarafa yönelik bir öfke yaşamalarına, çaresiz hissetmelerine ayrıca suçluluk duygusu yaşamalarına neden olmaktadır (Beycan Ekitli ve Çam, 2017). Tüm bunlara bakılarak LGBTİ bireylerin intihar davranışlarını bir halk sağlığı sorunu olarak ele almanın gerekli olduğu vurgulanabilir. LGBTI bireylerin maruz kaldıkları ayrımcılık ve dışlanma davranışları bireylerde çeşitli ruhsal hastalıkların görülmesine neden olmakta, bireylerin intihar davranışlarında bulunma riskini arttırmaktadır (Yalçınoğlu ve Önal, 2014). 
İntihar davranışlarında LGBTİ bireyler önemli bir risk grubunu oluşturmaktadır ve farklı cinsel yönelimleri nedeniyle intihara başvurma olasılıkları yüksektir. Ayrıca bu durum ergenlik döneminde daha fazla görülmektedir (Canetto ve Cleary, 2011).

LGBTI bireylerin toplum tarafından dışlanması, ötekileştirilmesinde toplumsal cinsiyet düzeni ve hegemonik erkeklik kavramsallaştırmasının etkisi göz ardı edilemez. Toplum bireylerden kadın ve erkek cinsiyeti için belirlediği ve onlara atfettiği değerler ve görevlere göre davranılmasını beklemekteyken LGBTİ bireylerin belirlenen sınırların dışına çıktığı düşünülmektedir. Farklı cinsel yönelim toplum tarafından kabul edilmemekte aksine belirli toplumsal değerlerin dışına çıkıldığı düşünülerek bireylerin toplumdan dışlanması söz konusu olmaktadır. Toplumsal normlara uyum sağlamadığı düşünülen bireyleri ötekileştirmek bireylerin sosyal izolasyonuna neden olmaktadır. Toplumsal cinsiyetin bireylerin hayatındaki bu izolasyon durumlarında ve olumsuz duygu durumlarında belirleyici olduğu ortadadır. Nitekim cinsiyet rolüne uygun davranmadığ 1 gerekçesiyle baskıya, şiddete, ayrımcılığa maruz kalan LGBTi bireyler intihar davranışına yönelebilmektedir. Diğer bir yandan hegemonik erkeklik kavramının belirlediği ve erkeklerin sahip olmasını beklediği önemli özelliklerden biri heteroseksüel olmalarıdır (Şimşek ve Öner, 2015). Heteroseksüellik erkekliğin göstergesi kabul edilmektedir (River, 2014). Heteroseksüelliği reddeden LGBTİ bireyler kadınsılı̆̆ı ifade eden özellikler ile nitelendirilerek toplum tarafından dışlanmaktadır. Toplum tarafından dışlanmak, erkeklik rollerini yerine getiremediği düşüncesiyle ayrımcılığa maruz kalmak LGBTİ bireylerin çözümsüz hissetmesine neden olabilmektedir.

\section{Intiharla Mücadelede Toplumsal Cinsiyete Duyarlı Sosyal Hizmet Uygulamaları}

Sosyal hizmet mesleği bireylerin, ailelerin ve toplumun yaşanan sosyal sorunlar ile baş etmelerini sağlamak ve bu kapsamda işlevselliklerini arttırmak gibi bir amaç üstlenmektedir (Yolcuoğlu, 2012). Sosyal hizmet uzmanları mikro, mezzo, makro düzeyde uygulamalarda bulunarak amaçlarını gerçekleştirmektedir. Mikro düzeyde birey ile birlikte 
çalışma, mezzo düzeyde aileler ve çeşitli küçük gruplarla birlikte çalışma ve makro düzeyde ise toplumsal düzeyde çalışmalar gerçekleştirme, sosyal politikalarda müracaatçı yararına değişim gerçekleştirme şeklinde çalışmalar yürütülmektedir (Zastrow, 2014).

Sosyal hizmet uzmanları insan haklarına, bireyin onur ve değerine saygı temeline sahip olan ve insanların refah durumlarını iyileştirmek adına çeşitli çalışmalar yürütmekte olan kişilerdir (Yolcuoğlu, 2012). Sosyal hizmet uzmanları toplumun her kesiminden farklı müracaatçı sistemleri ile karşılaşmakta (Zastrow, 2014) ve çalışmalarında genelci yaklaşımı kullanmaktadır. Genelci sosyal hizmet yaklaşımı bireyin çevresi içerisinde ele alınarak daha çok biyopsikososyal yönleri üzerinde durulmasını sağlamaktadır. Ayrıca genelci yaklaşım, ekosistem yaklaşımı ve çevresi içinde birey kavramını benimsemiş diğer yaklaşımlarla ortak birçok özelliğe sahiptir. Bu yaklaşım kapsamında uygulamalar üç düzeyde (mikro, mezzo, makro) gerçekleştirilmektedir (Özbesler ve Bulut, 2013). Birey, aile, grup ve toplumla çalışırken sosyal hizmet uzmanlarının yetkin olması beklenen birtakım roller bulunmaktadır. Bu roller destekleyici, vaka yöneticisi, kolaylaştırıcı, savunucu, aktivist, güçlendirici, eğitici, arabulucu, planlayıcı, kaynak bulucu, danışman, koordinatör gibi çeşitli rolleri kapsamaktadır (Zastrow, 2014; Özbesler ve Bulut, 2013).

Sosyal hizmet aile refahı, çocuk refahı, okul sosyal hizmeti, psikiyatrik sosyal hizmet gibi farklı çalışma alanlarına sahiptir (Yolcuoğlu, 2012). Uygulama alanları genelci sosyal hizmet yaklaşımı temel alarak oluşturulmaktadır. Bu kapsamda psikiyatrik sosyal hizmet de sosyal hizmetin uygulama alanlarından birisidir (Artan, 2013) ve tüm alanlarda olduğu gibi psikiyatrik sosyal hizmet alanında da sistem yaklaşımı, güçlendirme yaklaşımı, psikososyal yaklaşım, ekolojik yaklaşım gibi çeşitli temel yaklaşımlar kullanılmaktadır (Özbesler ve İçağasıŏ̆lu Çoban, 2010). Ruh sağlığı alanında sosyal hizmet mesleğinin kendisine has rolleri, sorumlulukları vardır ve bunlar çok boyutludur. Ruh sağlığı alanındaki sosyal hizmet uygulamalarının rolleri klinik düzey ve toplumsal düzey olarak sınıflandırılmaktadır. Bu sınıflandırmaya göre klinik düzeyde sosyal hizmet uzmanları "sosyal inceleme (müracaatçının ve sorunun tanımı, özgeçmiş, psikososyal değerlendirme, müdahale planı, anlaşma aşamalarını içermektedir.), psikoeğitim ve danışmanlık, taburculuk planlaması, 
bireyle çalışma, grup çalışması, savunuculuk, psikoterapi, hizmet içi eğitim koordinasyonu" gibi mikro, mezzo düzeyde roller üstlenmektedir. Toplumsal düzeyde ise "ruhsal risk taraması ve araştırma, koruyucu ruh sağh hizmetleri, sosyal içerme, toplum eğitimi, hizmet geliştirme" gibi roller üstlenmektedir (Oral ve Tuncay, 2012).

Sosyal hizmet ruh sağlığı alanında, intihar olgusuna yönelik birey, aile, grup ve toplumla çalışırken çeşitli sorumluluklar üstlenmektedir. Bu kapsamda intihar olgusu ile çalışmalar birincil, ikincil ve üçüncül düzeylerde önleme çalışmalarını kapsamaktadır. Birincil düzeyde sosyal hizmet uzmanları intihar olgusunu toplumsal düzeyde ele almaktadır. İntihar davranışına karşı toplum bilincini geliştirme, ulusal programlara katkı sağlama, intihar davranışının araştırılmasına yönelik çalışmalar gerçekleştirme gibi sorumluluklar bu düzeyde yer almaktadır. İkincil düzey çalışmalarda ise intihar davranışında risk faktörlerini belirleme ve buna göre müracaatçı sistemleri ile çalışmayı gerektirir. İntihar davranışında risk faktörlerinin belirlenmesi koruyucu çalışmaların başında gelmektedir. Risklerin bilinmesi önleyicilik açısından önemlidir. Üçüncül düzeyde çalışmalar ise bireylerin tedavisine yönelik sorumluluklar içermektedir. Tedavi sürecine ilişkin bireyin sorumlulukları ve ailelerin sorumlulukları dikkate alınarak çalışmalar gerçekleştirilmektedir (Alptekin, 2008).

İntihar davranışlarına yönelik mesleki uygulamalar yapmakta olan sosyal hizmet uzmanlarının toplumsal cinsiyete duyarlı uygulamalar gerçekleştirmesi gerekmektedir. İntihar davranışı üzerinde toplumsal cinsiyetin ne gibi bir rolünün olduğunun bilinmesi intihar davranışını önlemek açısından önemlidir. Toplumsal cinsiyet kadınlarda, erkeklerde ve LGBTI bireylerde intihar ve intihar girişimleri üzerinde belirleyici olmaktadır. İntiharla mücadelede toplumsal cinsiyete duyarlı sosyal hizmet uygulamalarını sosyal hizmetin planlı değişim süreci kapsamında ele almak mümkündür.

Planlı değişim sürecinin ilk aşaması olan karşılaşma/tanışma aşamasında sosyal hizmet uzmanı intihar girişiminden sağ kalan bireylerle genellikle sağlık hizmeti veren bir kuruluşta karşılaşabilmektedir. İntihar girişimi bireyin baş etme yöntemlerinin yetersiz kaldığı bir kriz durumudur ve bu durumda sosyal hizmet uzmanının krize müdahale yönteminin bilgisine başvurması gerekmektedir. Tanışma aşamasında 
sosyal hizmet uzmanının intihar girişiminden sağ kalan bireye güven vermesi önem taşımaktadır. Özellikle erkek müracaatçıların ruh sağlığ hizmetlerine başvurmaktan ve profesyonel yardım talep etmekten kaçındığı bilinen bir gerçektir. İntihar gibi kırılganlığın ve güçsüzlüğün ön planda olduğu travmatik bir deneyim söz konusu olduğunda ise erkek müracaatçıların kendini açması çok daha zor olabilmekte ve bu süreçte erkeklik normlarının önemli bir etkisi olabilmektedir. Dolayısıyla sosyal hizmet uzmanı yargılayıcı olmayan bir tutum sergileyerek anlama çabası içinde olduğunu hissettirerek bir güven ortamı oluşturmalı ve gizlilik ilkesini göz önünde bulundurmalıdır. Diğer bir yandan müracaatçı ile olan terapötik ilişkinin önemli dinamiklerinden biri de ruh sağlığı çalışanının cinsiyetidir. Bazı müracaatçılar çeşitli gerekçelerle kadın ya da erkek ruh sağlığı çalışanlarıyla daha rahat iletişim kurabildiklerini düşünebilmektedir. Örneğin bir cinsel saldırı sonrası intihar girişiminde bulunan kadın müracaatçının erkek ruh sağlığı çalışanı ile karşılaşmak istememesi son derece anlaşılır bir durumdur veya partneri tarafından terk edildikten sonra intihar girişiminde bulunan erkek müracaatçının kadınlara öfke duyması ve bu nedenle kadın ruh sağlığ çalışanları ile sağlıklı bir iletişim kuramayacağını ifade etmesi beklenen ve son derece olağan bir durumdur. Dolayısıyla intihar girişiminden sağ kalan bireylerin ruh sağlığ çalışanının cinsiyeti konusundaki hassasiyetlerine önem verilmelidir.

Planlı değişim sürecinin ön değerlendirme aşamasında sosyal hizmet uzmanı toplumsal cinsiyetin intihar girişimindeki etkisinin farkında olmalı ve müracaatçının intihar girişimiyle ilgili sosyal geçmişini bu farkındalıkla değerlendirmelidir. Kadına yönelik şiddet, işsizlik, yalnızlık, yoksulluk gibi intihar girişiminde etkili olabilecek birçok sorun doğrudan ya da dolaylı olarak toplumsal cinsiyet ile ilişkilidir. Sosyal hizmet uzmanı müracaatçının yaşadığı stres durumunun ve intihar girişiminin toplumsal cinsiyet ile ilişkisini gözden kaçırır ve değerlendirmesini bu şekilde yaparsa müracaatçıyı gerçek anlamda anlaması mümkün olmayacaktır. Diğer bir yandan toplumsal cinsiyet düzeninin bir çıtısı olan ayrımcı politika ve uygulamalar nedeniyle özellikle kadınlar ve LGBTI bireyler güçsüzlük ve kırılganlıkla daha fazla ilişkilendirilmektedir. Bu durum kadın ve LGBTI'lerin güçsüzlük ve kırılganlı̆̆ içselleştirmelerine neden olarak sahip oldukları gücün 
farkına varmalarını engellemektedir. Bu durumda sosyal hizmet uzmanının en önemli görevi kadınların ve LGBTI'lerin sahip oldukları güçlü yönlerini keşfetmelerine yardımcı olmak ve sosyal hizmet uygulamasını bu güçler üzerine inşa etmektir. Ön değerlendirme aşamasında intihar davranışında etkili olan makro düzeydeki dinamikleri de göz önünde bulundurmalıdır. Toplumda ruh sağlığı hizmetlerinin erişilebilir düzeyde olup olmadığı; toplumun mevcut ruh sağlığı hizmetleri konusundaki farkındalık düzeyi; kadınların, erkeklerin ve LGBTİlerin ruh sağlı̆̆ hizmetlerine erişimlerinde yapısal engeller olup olmadığı; mevcut ruh sağlığı hizmetlerinin toplumsal cinsiyete duyarlı olup olmadığı gibi birçok dinamiğin analiz edilmesi gereklidir.

Planlı değişim sürecinin planlama aşamasında sosyal hizmet uzmanı toplumsal cinsiyete duyarlı sosyal hizmet uygulamalarının bir gereği olarak güçsüzleştirici pratiklerden ve hiyerarşik ilişkilerden uzak durması ve planlama sürecini intihar girişiminde bulunan müracaatçı ile birlikte yapması gerekmektedir.

Müdahale aşamasında sosyal hizmet uzmanı intihar girişiminde bulunan bireyin toplumsal cinsiyete duyarlı terapilere erişiminin sağlanması ve benzer deneyimi yaşayan müracaatçılara yönelik grup çalışmalarının düzenlenmesi önemlidir. Müdahale aşamasında sosyal hizmet uzmanının müracaatçının farklılıklarını göz önünde bulundurması ve bu farklılıklar üzerinden müdahalenin planlanması gerekmektedir. Kadın, erkek ya da LGBTİ birey olmanın dışında farklı etnik köken, dini inanç gibi değişkenlerin de dikkate alınması toplumsal cinsiyete duyarlılık açısından gereklidir. Sosyal hizmet uzmanı toplumsal cinsiyetin ruh sağlığı üzerindeki etkisine yönelik bilinçlendirme çalışmaları veya ruh sağlığı çalışanlarına yönelik toplumsal cinsiyet eğitimi gibi çalışmalarla da farkındalık oluşturabilir. Söz konusu çalışmaların ardından sonlandırma ve son değerlendirme aşamasında intihar girişimine yönelik toplumsal cinsiyete duyarlı uygulamaların etkililiği analiz edilmeli ve müracaatçının bu süreçteki kazanımları değerlendirilmelidir. 


\section{Sonuç ve Tartışma}

Dünyada ve Türkiye'de intihar oranları önemli boyutlara ulaşmakta ve her geçen gün bu oranlar artmaktadır. Dünya Sağlık Örgütü her kırk saniyede birinin yaşamına son verdiğini ifade etmektedir. Bu çalışmada giderek artmakta olan intihar davranışında toplumsal cinsiyetin etkisi ortaya konmakta, intihar davranışında toplumsal cinsiyete duyarlı sosyal hizmet uygulamalarından bahsedilmektedir.

İntihar davranışlarında toplumsal cinsiyetin etkisi kadın, erkek ve LGBTİ bireylerin intihar davranışlarındaki bazı farklılıklar ile kendisini göstermektedir. Erkekler daha çok ekonomik kaygılar ve iş bulamama, herhangi bir durumda başarısız olma duyguları, yardım aramama davranışları, erkeklik algıları nedeniyle intihara başvurabilmektedir. Yöntem açısından bakıldığında erkekler yaşamı sonlandırma amacıyla intihara kalkışmakta ve ölüm riski daha fazla olan yöntemleri tercih etmektedir. $\mathrm{Bu}$ durum tamamlanmış intiharlarda erkek oranlarının fazla olmasıyla sonuçlanmaktadır. Kadınların intihar davranışında daha çok aile işi ilişkiler, sosyal destek alamama, ilişki sorunları etkili olabilmektedir ve intihar girişimlerinde kadın oranları daha fazladır. LGBTI'ler açısından bakıldığında toplumsal cinsiyet rolleri baskısının bir sonucu olarak toplum tarafından dişlanmak, ayrımcı davranışlara maruz kalmak intihar davranışlarında önemli nedenlerdendir. LGBTİ bireylerin intihar davranışlarında önemli bir risk grubu olduğunu belirtmek gerekir. Tüm bu farklılıklara bakıldığında intihar davranışı üzerinde toplumsal cinsiyetin önemli bir belirleyici olduğu anlaşılmaktadır.

Sosyal hizmet disiplininin çalışma alanlarından biri olan psikiyatrik sosyal hizmette intihar davranışına yönelik sosyal hizmet uzmanlarının önemli rol ve sorumlulukları bulunmaktadır. İntihar davranışı üzerinde toplumsal cinsiyetin önemli bir etkisi olduğu gerçeğinden hareketle sosyal hizmet uzmanlarının intiharla mücadele kapsamında toplumsal cinsiyete duyarlı uygulamalar gerçekleştirmesi gerekmektedir. $\mathrm{Bu}$ kapsamda sosyal hizmet bölümlerinde toplumsal cinsiyet odaklı derslerin zorunlu olarak verilmesi ve alanda çalışan sosyal hizmet uzmanlarına yönelik toplumsal cinsiyet eğitimi verilmesi önem taşımaktadır. 


\title{
EXTENDED ABSTRACT
}

\section{Suicide And Gender: An Evaluation From The Perspective Of Social Work}

\author{
Sinan Akçay_- Mervenur Taşkın \\ Selcuk University
}

Suicide is defined as intentionally taking one's own life. Suicide is generally considered in two ways as completed suicide and attempted suicide. Completed suicide results in death, while suicide attempts are selfdestructive behaviors but not death. Suicide is an increasing public health problem. World Health Organization stated that one person dies every 40 seconds from suicide. Therefore, the policies and services to be produced for suicidal behavior are an important need. In order to recognize and prevent this problem, it is important to know the risk factors and protective factors in suicidal behavior. Being between 15-25 years of age, being single, low education level, presence of mental illness or psychiatric diagnosis are some of the risk factors for suicidal behavior (Özel et al., 2008; Önsüz et al, 2012; Arslan et al., 2008; Dilbaz et al., 2005; Yavuz et al., 2006; Şevik et al., 2012; Karamustafalığlu et al., 2010; Swan et al., 2002; Fennig et al., 2005; Atay et al., 2012; Kessler et al., 1999). Factors such as commitment to life, satisfaction with health status, help-seeking behavior and social support are protective factors (Atay et al., 2012; Gürkan and Dirik, 2009; Batıgün, 2008).

One of the important determinants of suicidal behavior is gender. Gender refers to the shaping of the roles and responsibilities of women and men within the framework of social values. Gender reflections are manifested in mental health as well as in many other fields. According to Turkish Statistical Institute's data $72.7 \%$ of the completed suicide consists of men. In other words, men die due to suicide approximately three times more than women. The concept of success in male suicidal behaviors comes to the forefront. In this context, completed suicide is associated with success and survival after suicide attempt is associated with failure. Gender norms and conceptualization of hegemonic masculinity have an important effect on males' expressing their feelings, not asking for help and perceiving seeking help as weakness. The rate of women in 
completed suicides is $27.3 \%$ (Turkish Statistical Institute, 2015). So it is emphasized that completed suicide rates are higher in males and suicide attempts are higher in females. Family-related problems are at the forefront of female suicidal behavior. On the other hand, LGBTI individuals who are excluded by the society and encounter negative attitudes may experience various psychological problems. This increases the risk of suicide in LGBTI individuals and determines the suicidal behavior.

The social work profession carries out practices in various areas for individual, family, group and community problems. Mental health is one of the important practice areas of the social work profession. Social workers have some responsibilities in working with suicide behavior in the field of mental health. In this article, social work practices aimed at preventing suicidal behavior are discussed within the scope of planned change process. Social worker should carry out gender-sensitive practices at every stage of planned change process.

This article demonstrates the effect of gender on suicidal behavior and discusses gender-sensitive social work practices. The reasons such as unemployment, financial concerns and failure are effective in men's suicidal behavior and they prefer more lethal methods. Women prefer methods that are less likely to result in death and have a higher rate of suicide attempts. Exclusion of LGBTI individuals by society and exposure to negative behaviors may result in suicide. All this shows that gender is an important determinant of suicidal behavior. Because of that, social workers should carry out gender-sensitive practices in terms of preventing suicide. In this context, it is recommended that genderoriented courses should be compulsory in the social work departments and gender education should be given to the social workers working in the field.

\section{Kaynakça / References}

Alptekin, K. (2008). Sosyal hizmet bakış açısından genç yetişkinlerde intihar girişimlerinin incelemesi: Bir model önerisi. Yayımlanmamış Doktora Tezi. Hacettepe Üniversitesi Sosyal Bilimler Enstitüsü, Ankara.

Altınova, H.H. ve Duyan, V. (2013). Toplumsal cinsiyet algısı ölçeğinin geçerlik güvenirlik çalışması. Toplum ve Sosyal Hizmet, 24(2), 9-22. 
Ançel, G. (2018). Ruh Sağlığında Cinsiyete Duyarlılık. (A. İçağasığlu, ve S. Attepe Özden), Psikiyatrik Sosyal Hizmet içinde (s. 331-342). Ankara: Nobel Akademik Yayıncllık

Arslan, M., Duru, M., Kuvandik, G., Bozkurt, S., ve Kaya, E. (2008). Hatay' da intihar girişiminde bulunan olguların analizi. Adli Tıp Dergisi, 22(3), 9-14.

Artan, T. (2013). Hastane sosyal hizmeti. (H. Acar, N. Negiz, ve E. Akman), Sosyal Politika ve Kamu Yönetimi Bileşenleriyle Sosyal Hizmet Temelleri ve Uygulama Alanları içinde (s. 235-248). Ankara: Maya Akademi.

Batıgün, A. D. (2008). İntihar olasıllğı ve cinsiyet: iletişim becerileri, yaşamı sürdürme nedenleri, yalnızlık ve umutsuzluk açısından bir inceleme. Türk Psikoloji Dergisi, 23(62), 65-75.

Beycan Ekitli, G. ve Çam, M. O. (2017). Bakım sürecinde zorlandığımız alan lgbti'ye yönelik bir gözden geçirme. Psikiyatri Hemşireliği Dergisi, 8(3),179-187.

Canetto, S.S. and Cleary, A. (2011). Men, Masculinities And Suicidal Behaviour. Social Science \& Medicine. 74 (2012), 461-465.

Canetto, S.S., and Lester, D. (1998). Gender, culture and suicidal behavior. Transcultural Psychiatry, 35(2), 163-190.

Cleary, A. (2012). Suicidal action, emotional expression, and the performance of masculinities. Social Science and Medicine. 74(4), 498-505.

Connell R.W. and Messerschmidt, J.W. (2005). Hegemonic Masculinity Rethinking the Concept. Gender \& Society, 19(6), 829-859.

Demirgöz-Bal, M. (2014). Toplumsal cinsiyet eşitsizliğine genel bakış, KASHED, 1(1), 15-28.

Dilbaz, N., Şengül, S., Çetin, M., Şengül, C., Okay, T., Yurtkulu, F., and Duman, T. (2005). Genel Bir Hastanede İntihar Girişimlerinin Değerlendirilmesi. Kriz Dergisi, 13(2), 1-10.

Erdoğan, B. and Köten, E. (2015). As kendini de hepimiz kurtulalım artık!: Sosyal dişlanmadan intihara lgbt gençler. Alternatif Politika, 7(1), 143-167.

Fennig, S., Geva, K., Zalsman, G., Weizman, A., Fennig, S. ve Apter, A. (2005). Effect of gender on suicide attempters versus nonattempters in an adolescent inpatient unit. Comprehensive Psychiatry, 46, 90-97

Gürkan, B., and Dirik, G. (2009). Üniversite öğrencilerinde intihar düşünce ve davranışları ile ilişkili faktörler: Yaşamı sürdürme nedenleri ve baş etme yolları. Türk Psikoloji Yazırları Dergisi, 12(24), 58-69. 
İntihar İstatistikleri. (2015, Haziran). TÜİK [Haber Bülteni]. 17.05.2019 tarihinde $\quad$ http://www.tuik.gov.tr/PreHaberBultenleri.do?id=21516 adresinden erişilmiştir.

Karamustafalığlu, O., Özçelik, B., Bakım, B., Cengiz Ceylan, Y., Göksan Yavuz, B., Güven, T., ve Gönenli, S. (2010). İntihari öngörebilecek bir araç: Hastane anksiyete ve depresyon ölçeği. Düşünen Adam Psikiyatri ve Nörolojik Bilimler Dergisi, 23(3), 151-157.

Kessler, R., Borges, G., ve Walters, E. (1999). Prevalence of and risk factors for lifetime suicide attempts in the national comorbidity survey. Arch Gen Psychiatry, 56(7), 617-26.

Kuğu, N., Beyaztaş, F., Aküz, G., Erşan, E., ve Doğan, O. (2002). Sivas İl Merkezinde Üniversite Hastanesine İntihar Girişimi Nedeniyle Getirilen Olgularda Sosyodemografik-Klinik Özellikler, Beck Depresyon Ölçeği ve SCL-R Sonuçları. Klinik Adli Tip Dergisi, 2(2), 15-26.

Kurt-Topuz, S. (2016). Toplumsal cinsiyet bağlamında kadın ve erkeğe atfedilen anlamların metafor yöntemiyle analizi. Alternatif Politika, $8(2), 300-321$.

Langhinrichsen-Rohling, J., Lewinsohn, P., Rohde, P., Seeley, J., M. Monson, C., A. Meyer, K., ve Langford, R. (1998). Gender Differences in the Suicide- Related Behaviors of adolescents and young adults. Sex Roles a journal of Research, 1, 1-10.

Lubell, K.M. (2001). Gender, social isolation and psychopathology: Makng sende of male-female differences in suicide mortality. Indiana University Sociology Department Doctoral Distertation.

McAndrew, T. F., and J. Garrison, A. (2007). Beliefs about gender differences in methods and cauuses of suicide. Archives of Suicide Research, 11, 19.

Moller-Leimkuhler, A.M. (2003). The gender gap in suicide and premature death or: Why are men so vulnerable? Eur Arch Psychiatry Clin Neurosci. 253(1), 1-8.

National LGBTI Health Alliance. (2016). Snapshot Of Mental Health And Succde Prevention Statistics For LGBTI People. 20.05.2019 tarihinde https://lgbtihealth.org.au/statistics/adresinden erişilmiştir.

Önsüz, M., Demir, F., Kaya Afşari, E., Şahin, A., Çatalbaş, Y., ve Bektaş, H. (2012). Sakarya ilinde gerçekleşen intihar girişimi vakalarının değerlendirilmesi. Türkiye Halk Sağlığı Dergisi, 10(3), 141-150. 
Oral, M., ve Tuncay, T. (2012). Ruh sağllğı alanında sosyal hizmet uzmanlarının rol ve sorumlulukları. Toplum ve Soryal Hizmet Dergisi, 23(2), 93-114.

Özbesler, C., ve Bulut, I. (2013). Sosyal hizmette genelci yaklaşım ve ekolojik perspektif. (H. Acar, N. Negiz, ve E. Akman) içinde, Sosyal Politika ve Kamu Yönetimi Bileşenleriyle Sosyal Hizmet Temelleri ve Uygulama Alanları içinde (s. 97-108). Ankara: Maya Akademi.

Özbesler, C., ve İçağasıoğlı Çoban, A. (2010). Hastane ortamında sosyal hizmet uygulamaları: Ankara örneği. Toplum ve Sosyal Hizmet, 31-46.

Özel, A., Keser, N., ve Köksal, E. (2008). İntihar ve intihara teşebbüs eden bireylerin cinsiyeti, eğitim düzeyleri ve coğrafya dağılımları: Kütahya şehri örneği. Eastern Geographical Review, 13(19), 231-250.

River, J. (2014). Suicide and hegemonic masculinity: Australian case studies. In (D. Lester, J.F. Gunn \& P. Quinnett), Suicide in Men, Charles C Thomas Publisher, Illinois.

Scourfield, J., Jacob, N., Smalley, N., Prior, L. ve Greenland, K. (2007). Young people's gendered interpretations of suicide and attempted suicide. Child and Family Social Work, 12, 248-257.

Şevik, A., Özcan, H., ve Uysal, E. (2012). İntihar girişimlerinin incelenmesi: risk faktörleri ve takip. Klinik Psikiyatri Dergisi, 15, 218-225.

Şimşek A.A. ve Öner R. V. (2015). Türkiye'de hegemonik erkeklik: Medyada ve hukukta izler, dönüşümler ve olasılıklar. Global Media Journal TR Edition, 6(11), 447-477.

Siyez, D. M. (2006). Ergenlik döneminde intihar girişimleri: Bir gözden geçirme. Kastamonu Ĕ̆itim Dergisi, 14(2), 413-420.

Swami, V., Stanistreet, D., ve Payne, S. (2008). Masculinities and Suicide. Psychologist, 21(4), 308-311.

World Health Organization (DSÖ) (2014). Preventing suicide: A global imperative. 19.05.2019 tarihinde https://www.who.int/mental health/suicideprevention/world report 2014/en/ adresinden erişilmiştir.

Yalçınoğlu, N. ve Önal A.E. (2014). Eşcinsel ve biseksüel erkeklerin içselleştirilmiş homofobi düzeyi ve sağlık üzerine etkileri. Turk J Public Health, 12(2), 100-112.

Yaşar, M. R. (2007). Depresyonun kadınlaşması. Fırat Üniversitesi SosyalBilimler Dergisi, 17(2), 251-281. 
Yavuz, Y., Yürümez, Y., Küçüker, H., Demirel, R., ve Küçük, E. (2006). İntihar sonucu meydana gelen ölümlerin incelenmesi. Genel Tip Dergisi, 16(4), 181-185.

Yolcuoğlu, İ. G. (2012). Sosyal hizmete giriş. Ankara: Sabev.

Yumru, M., Savaş, H. A., Herken, H. ve Kokaçya, M. H. (2008). İntihar ve kişilik. Anadolu Psikiyatri Dergisi, 9(4), 232-237.

Zastrow, C. (2014). Sosyal hizmete giriş. Ankara: Nika.

\section{Kaynakça Bilgisi / Citation Information}

Akçay, S. ve Taşkın, M. (2019). İntihar ve toplumsal cinsiyet: Sosyal hizmet perspektifinden bir değerlendirme. OPUS-Uluslararası Toplum Araştırmaları Dergisi, 14(20), 2278-2299. DOI: 10.26466/ opus. 605613 